\title{
INEL Operable Unit 7-13 Containment and Stabilization Configuration Option
}

\author{
B. D. Raivo \\ J. G. Richardson \\ D. F. Nickelson
}

Published May 1993

Idaho National Engineering Laboratory

EG\&G Idaho, Inc.

Idaho Falls, Idaho 83415

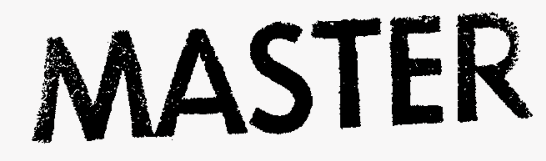

Prepared for the

U.S. Department of Energy

Office of Environmental Restoration and Waste Management

Under DOE Idaho Operations Office

Contract DE-AC07-76ID01570 


\section{DISCLAIMER}

This report was prepared as an account of work sponsored by an agency of the United States Government. Neither the United States Government nor any agency thereof, nor any of their employees, make any warranty, express or implied, or assumes any legal liability or responsibility for the accuracy, completeness, or usefulness of any information, apparatus, product, or process disciosed, or represents that its use would not infringe privately owned rights. Reference herein to any specific commercial product, process, or service by trade name, trademark, manufacturer, or otherwise does not necessarily constitute or imply its endorsement, recommendation, or favoring by the United States Government or any agency thereof. The views and opinions of authors expressed herein do not necessarily state or reflect those of the United States Government or any agency thereof. 


\section{DISCLAIMER}

Portions of this document may be illegible in electronic image products. Images are produced from the best available original document. 


\section{INEL Operable Unit 7-13 Containment and Stabilization Configuration Option}

EGG-WTD-10651

Prepared by

Mylatalon

D. F. Nickelson, S\&E Project Manager

Environmental Restoration Technology Development
$5-14-93$

Date

Reviewed by

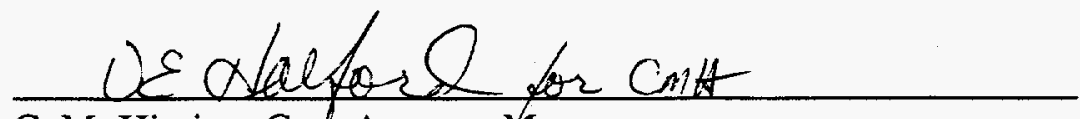

C. M. Hiaring, Cost Account Manager

Buried Waste Program

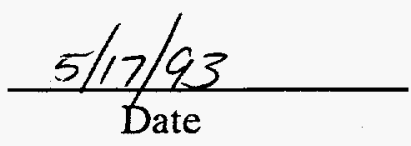

Approved by
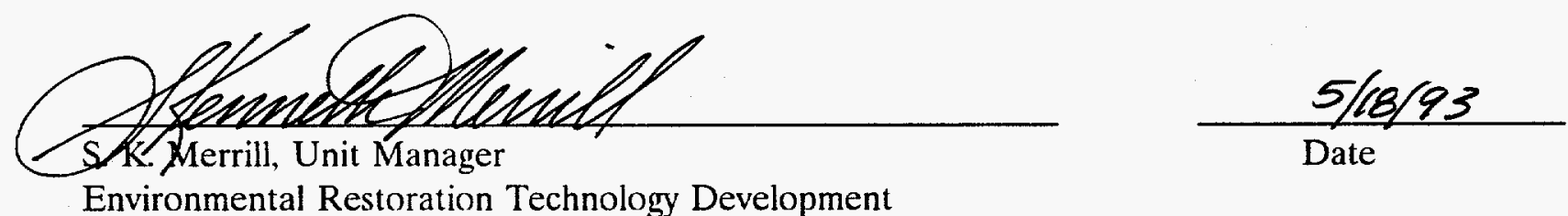


\section{ABSTRACT}

A containment and stabilization configuration option has been developed for the Idaho National Engineering Laboratory's Subsurface Disposal Area Operable Unit 7-13, the transuranic (TRU)-contaminated waste pits and trenches. The configuration option is presented as an end-to-end system block diagram. Functional subelements are separately discussed, and technical background information, assumptions, input, high-level subelement requirements, and output are presented for each option. 


\section{SUMMARY}

The mission of the Buried Waste Integrated Demonstration (BWID) systems analysis project is to identify and evaluate cradle-to-grave systems for the remediation of transuranic (TRU)-contaminated waste pits and trenches within the Subsurface Disposal Area of the Radioactive Waste Management Complex at the Idaho National Engineering Laboratory. The BWID program will use the results of the BWID systems analysis in conjunction with identified U. S. Department of Energy (DOE) complex buried waste needs to develop a long-term strategy for improving buried waste remediation capabilities throughout the DOE system.

This report presents a containment and stabilization configuration option concept in the form of a block diagram. Associated with each subelement are high-level input, output, and functional requirements. These requirements will be used to screen and evaluate candidate remedial technologies (future work). This methodology provides a systematic approach to selecting potential technologies for consideration during Comprehensive Environmental Response, Compensation, and Liability Act treatability and feasibility studies. 


\section{CONTENTS}

ABSTRACT $\ldots \ldots \ldots \ldots \ldots \ldots \ldots \ldots \ldots \ldots \ldots \ldots \ldots \ldots \ldots \ldots \ldots \ldots \ldots \ldots$

$\operatorname{SUMMARY} \ldots \ldots \ldots \ldots \ldots \ldots \ldots \ldots \ldots \ldots \ldots \ldots \ldots \ldots \ldots \ldots \ldots \ldots$

ACRONYMS $\ldots \ldots \ldots \ldots \ldots \ldots \ldots \ldots \ldots \ldots \ldots \ldots \ldots \ldots \ldots \ldots \ldots \ldots \ldots \ldots \ldots$

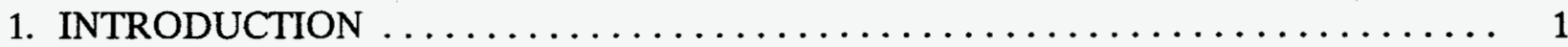

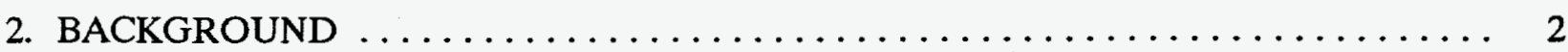

3. CONFIGURATION OPTION OVERVIEW $\ldots \ldots \ldots \ldots \ldots \ldots \ldots \ldots \ldots \ldots \ldots$

3.1 Configuration Option Functional Subelement Discussions $\ldots \ldots \ldots \ldots \ldots \ldots$

3.1.1 Functional Subelement 1.0 Site/Waste Characterization $\ldots \ldots \ldots \ldots \ldots \ldots \ldots$

3.1.2 Functional Subelement 2.0 Hot Spot Remediation $\ldots \ldots \ldots \ldots \ldots \ldots \ldots \ldots$

3.1.3 Functional Subelement 3.0 Site Preparation $\ldots \ldots \ldots \ldots \ldots \ldots \ldots \ldots \ldots$

3.1.4 Functional Subelement 4.0 Abovegrade Confinement . . . . . . . . . . . 10

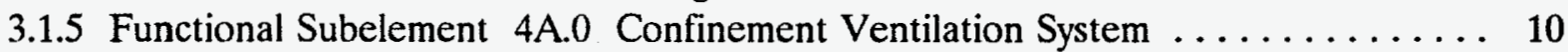

3.1.6 Functional Subelement 4B.0 Confinement Ventilation Residuals/Solids Disposal . 11

3.1.7 Functional Subelement 5.0 Interim Vertical Barriers .............. 11

3.1.8 Functional Subelement 6.0 Permanent Vertical Barriers . . . . . . . . . . . . 13

3.1 .9 Functional Subelement 7.0 Temporary Cap $\ldots \ldots \ldots \ldots \ldots \ldots \ldots \ldots \ldots \ldots$

3.1.10 Functional Subelement 8.0 Permanent Bottom Barrier $\ldots \ldots \ldots \ldots \ldots \ldots \ldots 14$

3.1.11 Functional Subelement 9.0 Monitor and Interim Assessment $\ldots \ldots \ldots \ldots \ldots$

3.1.12 Functional Subelement 10.0 Vapor Extraction $\ldots \ldots \ldots \ldots \ldots \ldots \ldots$

3.1.13 Functional Subelement 10A.0 Offgas Treatment System . . . . . . . . . 16

3.1.14 Functional Subelement 10B.0 Offgas Treatment Residual Solid Disposal $\ldots \ldots 17$

3.1.15 Functional Subelement 11.0 Final Action $\ldots \ldots \ldots \ldots \ldots \ldots \ldots \ldots \ldots$

4. REFERENCES $\ldots \ldots \ldots \ldots \ldots \ldots \ldots \ldots \ldots \ldots \ldots \ldots \ldots \ldots \ldots \ldots \ldots$

\section{FIGURES}

1. Containment and stabilization configuration option for SDA OU $7-13 \ldots \ldots \ldots$

2. Cross-section of a typical OU $7-13$ waste pit or trench. $\ldots \ldots \ldots \ldots \ldots \ldots \ldots$

3. Existing wells and boreholes at the RWMC $\ldots \ldots \ldots \ldots \ldots \ldots \ldots \ldots \ldots \ldots \ldots$ 


\section{ACRONYMS}

ARAR Applicable or relevant and appropriate requirement

BWID Buried Waste Integrated Demonstration

CERCLA Comprehensive Environmental Response, Compensation, and Liability Act

DOE U.S. Department of Energy

DRE Destruction Removal Efficiency

EPA Environmental Protection Agency

F\&OR Functional and operational requirements

INEL Idaho National Engineering Laboratory

LLW Low-level waste

OU Operable unit

ROD Record of Decision

RWMC Radioactive Waste Management Complex

SDA Subsurface Disposal Area

TRU Transuranic

VOC Volatile organic compound

WAC Waste Acceptance Criteria 


\section{INEL Operable Unit 7-13 Containment and Stabilization Configuration Option}

\section{INTRODUCTION}

This report presents a buried waste containment and stabilization configuration option concept and discusses input, output, and general requirements for each functional subelement. A configuration option is defined in the systems analysis project as a top-level block diagram of a cradle-to-grave remedial option whose overall performance is specified by system requirements.

In depth investigation of a containment and stabilization configuration option is not meant to champion this option or meant to preclude other configuration options that may meet system requirements. Several configuration options describing a buried waste retrieval and ex situ thermal treatment remedial scenario were developed by the systems analysis project team in $1992 .{ }^{1}$ Additional configuration options may be considered within the Buried Waste Integrated Demonstration (BWID) Program at a later date. 


\section{BACKGROUND}

The mission of the BWID systems analysis project is to identify and evaluate cradle-to-grave systems for the remediation of transuranic (TRU)-contaminated waste pits and trenches within the Subsurface Disposal Area (SDA) of the Radioactive Waste Management Complex (RWMC) at the Idaho National Engineering Laboratory (INEL). There are three objectives of the project:

1. Direct U.S. Department of Energy (DOE) resources to develop technically sound and cost-effective systems for the complete remediation of DOE buried waste sites

2. Guide the selection and technical justification for the development and demonstration of technologies within the BWID and treatability studies in the Environmental Restoration TRU-Contaminated Waste Pits and Trenches Operable Unit

3. Identify system technology gaps and define quantitative performance requirements for technologies associated with the remediation of DOE complex buried wastes.

The BWID Program uses the results of the BWID systems analysis in conjunction with identified DOE complex buried waste needs to develop a long-term strategy for improving buried waste remediation capabilities throughout the DOE system.

Before identifying configuration options for cradle-to-grave remediation of TRU-contaminated waste pits and trenches [designated as Operable Unit (OU) 7-13], system requirements must be identified. System requirements are defined as a set of top-level constraints that direct the overall process. System requirements will be used to identify and select viable remedial options from a number of candidate options. The performance of a remediation option is restricted by requirements such as waste/site characteristics, applicable or relevant and appropriate requirements (ARARs), and programmatic requirements defined by the Environmental Protection Agency (EPA), DOE, and State of Idaho. System requirements are not the same as functional and operational requirements (F\&ORs) associated with each of the steps within a particular option. F\&ORs are described as a set of function and operation requirements that meet system requirements.

Proposed system requirements, published in an earlier report, ${ }^{2}$ have been generated from a combination of technical and regulatory sources and are divided into the following categories:

- $\quad$ Programmatic requirements

- Federal Facility Agreement and Consent Order (EPA, DOE, and State of Idaho) ${ }^{3}$

- $\quad$ Buried Waste Integrated Demonstration Strategy Plan ${ }^{4}$

- INEL Environmental Restoration planning and development assumptions presented in a predecisional draft INEL Environmental Restoration roadmap document ${ }^{\mathrm{a}}$

\footnotetext{
a. Idaho National Engineering Laboratory, INEL Environmental Restoration Roadmap, December 1991.
} 
- INEL Waste Management Operations planning and development assumptions presented in a predecisional draft INEL Waste Management Operations roadmap document $^{b}$

- Input requirements

- Historical and technical characterizations of the INEL SDA ${ }^{5, c}$

- Output requirements

- $\quad$ INEL RWMC Low-Level Waste Acceptance Criteria (LLW WAC) ${ }^{6}$

- INEL TRU WAC

- INEL RWMC Pad A ARARs. d

Each block within a configuration option performs a function, referred to as a functional subelement. General input, output, and functional requirements are defined for each functional subelement of the containment and stabilization configuration option. The requirements direct inserting specific technologies into each functional subelement that results in formulation of technology process options (systems). A technology process option is a Comprehensive Environmental Response, Compensation, and Liability Act (CERCLA) term used to describe a configuration option that has specific technologies or requirements defined for all functional subelements. The terms "system" and "technology process option" are used synonymously in the systems analysis project.

b. Idaho National Engineering Laboratory, INEL Waste Management Operations Roadmap, September 1991.

c. D. A. Arrenholz and J. L. Knight, Historical Report of Transuranic Waste Pits and Trenches at the Subsurface Disposal Area of the Radioactive Waste Management Complex at the INEL, WTD-91-027, August 1991.

d. Letter from S. G. Stiger, INEL Environmental Restoration, to W. N. Sato, DOE-ID, "Transmittal of the Revised Pad A Technical Memorandum on the Preliminary Identification of Combined Federal and State Applicable or Relevant and Appropriate Requirements (ARARs)," SGS-515-91, December 5, 1991. 


\section{CONFIGURATION OPTION OVERVIEW}

This containment and stabilization configuration option consists of 11 subelements (see Figure 1). These are divided into six classes of activities: (1) characterization, (2) interim isolation (3) monitoring and assessment, (4) treatment, (5) emissions and disposal, and (6) final action. These activities are summarized below.

Initially, the SDA will be characterized to define or validate major waste constituents and pit and trench physical boundaries. Detailed surface and basalt elevation surveys will also be obtained to assist in design of the remedial actions. Remediation will then be performed on "hot spots." Hot spots are areas within the pits and trenches that pose significantly more risk to the environment than surrounding areas. Within the context of this particular configuration option, it is postulated that remediation of these areas, above and beyond containment, will significantly reduce the overall risk posed by the site. The detection (and definition) of hot spots and associated requirements are outside the scope of this report and are not covered in detail. Future systems analysis project activities will investigate hot spot remediation.

Following hot spot remediation, the site will be prepared for installation of the containment system (e.g., surface drainage improvements, and monitoring well installation). Next, vertical barriers will be installed surrounding the pits and trenches. These will be installed in an incremental method that is prioritized by the baseline risk assessment. Barriers that are placed between pits and trenches are considered temporary, or interim, and those barriers placed external to pits and trenches designated for containment are permanent. Eventually, all designated pits and trenches will be surrounded by a permanent barrier.

Because each area is contained within vertical barriers (either permanent or temporary), it will be covered with a temporary cap. Also, during the barrier and temporary capping activity, a best effort horizontal bottom barrier will be emplaced. The contained wastes and surrounding soils will then be monitored, and interim assessments performed.

Following interim containment and continuing for a period of 10 to 50 years, vapor extraction will be performed to remove volatile organics from the containment. After removal of volatile organics, a permanent cap will be installed as the final action.

This configuration option also includes support functions that meet the requirements for confinement, ventilation, offgas treatment, and residuals disposal. Most of the defined subelement activities will be driven by the results of a baseline risk assessment and reductions in risk that can be attained by implementing specific remedial actions.

\subsection{Configuration Option Functional Subelement Discussions}

This section presents the initial development of the remedial configuration option. Basic technical information, assumptions, and input and output requirements are defined for each functional subelement. 


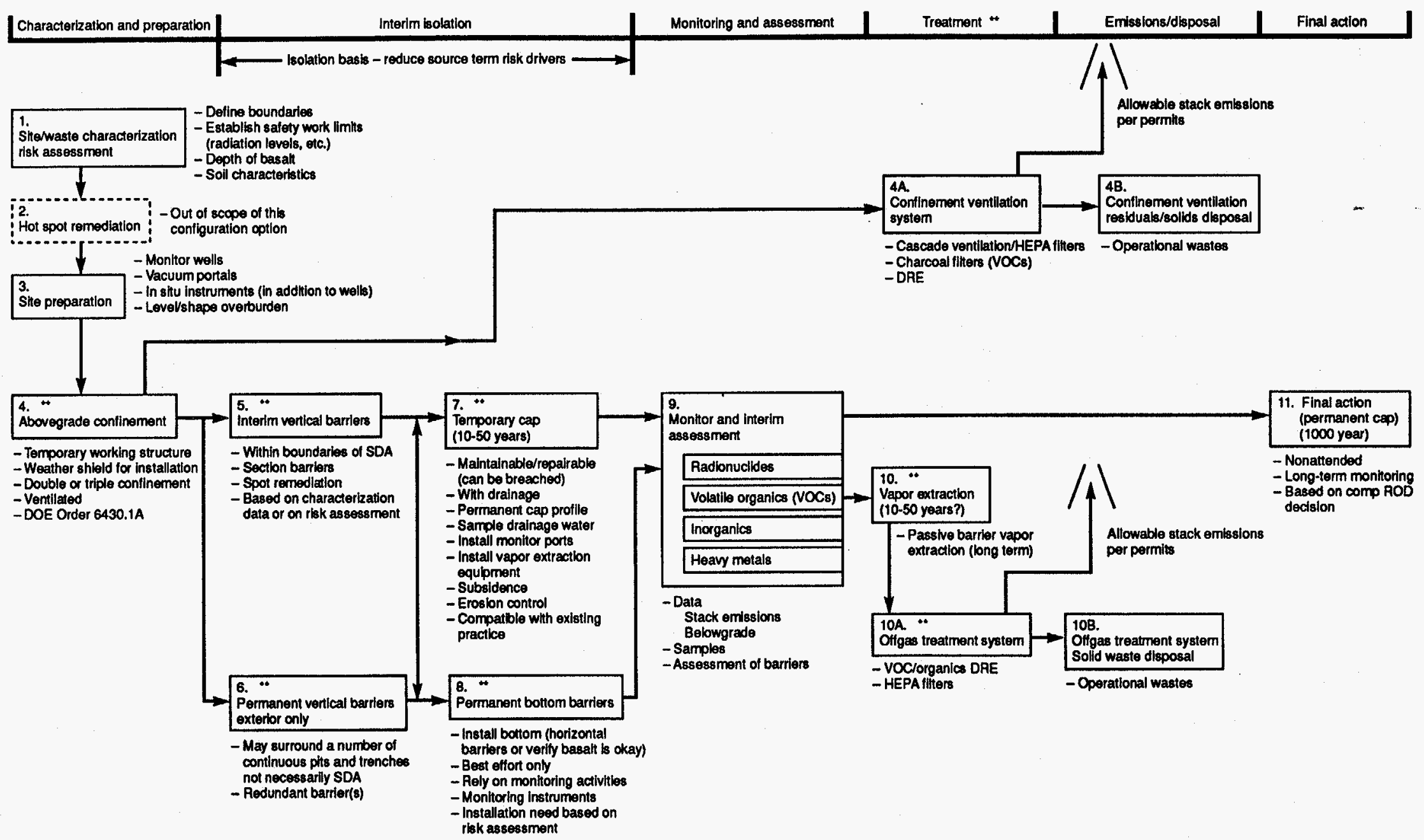

". The subelements denoted by "* indicate that an action or no action is based on the results of a risk assessment.

Figure 1. Containment and stabilization configuration option for SDA OU 7-13. 


\subsubsection{Functional Subelement 1.0 Site/Waste Characterization}

3.1.1.1 Background Technical Information and Assumptions. Requirements for this subelement support the performance of the containment and stabilization activities. Additional requirements may have to be met for hot spot remediation activity. Hot spot remediation is outside the scope of this report and will be addressed independently in a later study.

The waste pits were excavated to the underlying basalt layer and generally backfilled with 2 to $5 \mathrm{ft}$ of soil to provide a level floor. The waste trenches were generally excavated to the basalt layer, approximately $10 \mathrm{ft}$ down, averaging $7 \mathrm{ft}$ wide, and up to $1800 \mathrm{ft}$ long. The waste pits were excavated approximately $15 \mathrm{ft}$ down. Following excavation, wastes were placed into the pits and trenches. From 1952 to 1963 , the waste containers were stacked to optimize disposal space. During 1963 to 1969 , the waste packages were randomly dumped into the pits and trenches to limit radiation exposure to workers. In 1969, the waste containers were again stacked to optimize disposal volume. Once emplaced, the wastes were backfilled and covered with silty clay and sandy soil.

Physical dimensions of each waste pit and trench (including overburden) are given in Appendix A, Tables A-1, A-2, and A-3. Details of the characteristics of INEL RWMC soils are given in Appendix A, Tables A-4 through A-8.

Figure 2 illustrates a cross-section of a typical OU 7-13 waste pit or trench and identifies terms used throughout this report.

The assumptions for this subelement are

- $\quad$ Maximum depth of the pits and trenches is $25 \mathrm{ft}$.

- Chemical and mineral composition of the overburden soil can be used to estimate the composition of the sideburden, underburden, and interstitial soils.

- Waste pits and trenches will be isolated and capped in stages.

- Stabilization final action (subelement 11.0) will be based on the comprehensive Record of Decision (ROD) and may be a permanent cap with a 1000-year design lifetime.

- Existing data are insufficient to administratively locate the placement of interim or permanent walls. The adequacy of wall locations shall be verified (using nonintrusive investigation) for unknown waste locations before construction.

3.1.1.2 Input. The input will include TRU-contaminated waste from pits and trenches located at the INEL SDA (designated as OU 7-13).

3.1.1.3 Requirements. The following will be determined during site/waste characterization:

- Vertical boundaries of the waste pits and trenches

- Depth of the basalt underlying the waste pits and trenches 

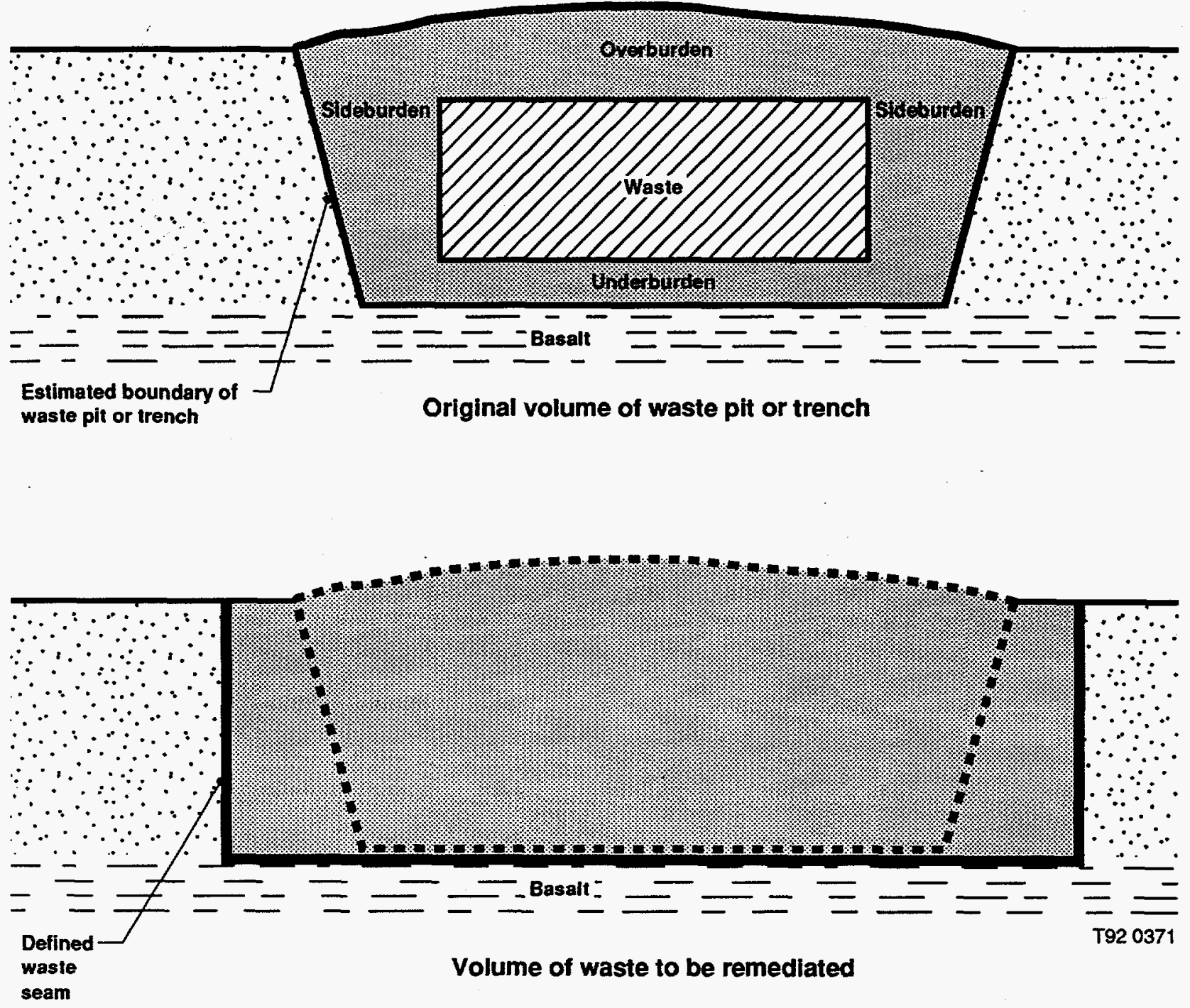

Figure 2. Cross-section of a typical OU 7-13 waste pit or trench. 
- Depth of overburden/waste interface for each waste pit and trench

- Highest 100 and 500-year water table level

- Mean concentration and major constituents of organic volatiles in each pit or trench area to be isolated

- Soil physical characterization.

3.1.1.4 Output. The output will be

- $\quad$ Estimated boundaries of TRU-contaminated waste pits and trenches

- $\quad$ Highest 100 and 500-year water table level

- Mean concentration and major constituents of organic volatiles in each pit or trench area to be isolated

- Detailed elevation survey (basalt and ground levels) for the SDA.

\subsubsection{Functional Subelement 2.0 Hot Spot Remediation}

3.1.2.1 Background Technical Information and Assumptions. A detailed examination of spot remediation activity is outside of the scope of this report. The containment and stabilization configuration option assumes that the volume fraction of the OU-13 pits and trenches that cannot be safely capped and isolated will be retrieved or stabilized in place. The requirements for identifying and remediating these locations are not defined here.

The hot spot remediation activity will include further characterization, remediation, and postremediation restoration or replacement of the overburden, if necessary.

3.1.2.2 Input. The input will be TRU-contaminated waste from pits and trenches located at the INEL SDA (designated as OU 7-13).

3.1.2.3 Requirements. The requirements will include

- Characterization to identify boundaries of waste volume to be remediated

- $\quad$ Remediation of the volume of the OU-13 pits and trenches that cannot be safely capped and isolated

- Restoration or replacement of overburden to original contour/profile. 
3.1.2.4 Output. The output will be a remediated volume with original surface profile.

\subsubsection{Functional Subelement 3.0 Site Preparation}

3.1.3.1 Background Technical Information and Assumptions. The assumptions for this subelement are

- Hot spot remediation of selected locations will be performed before capping.

- No overburden will be removed as a part of this activity, except that necessary to emplace wells and in situ instruments.

- Additional overburden can be added and shaped to ensure adequate drainage off a waterproof cap.

- All potential cells within a subarea can be made to drain adequately into temporary runoff channels. It will be acceptable to add temporary berms during the interim vertical barriers and temporary cap activity to accomplish this.

- All containment and stabilization construction activities will take place above the highest 100 or 500 -year water table level.

3.1.3.2 Input. The input will include

- Detailed elevation of the SDA

- Estimated boundaries of TRU-contaminated waste pits and trenches

- $\quad$ Highest 100 and 500-year water table level.

3.1.3.3 Requirements. The requirements will include

- Identify subareas for caps

- Contour site by adding overburden soil to facilitate construction of a surface cap for drainage

- Prepare site to enable additional monitor wells/and or vacuum portals to be installed before or after stabilizing and capping activities

- Install in situ measurement instrumentation for monitoring activities.

3.1.3.4 Output. The output will include

- Locations of subareas that will share caps

- Additional overburden emplaced to shape subareas for drainage 
- Additional monitor wells

- Vacuum portals

- In situ measurement instruments installed.

\subsubsection{Functional Subelement 4.0 Abovegrade Confinement}

3.1.4.1 Background Technical Information and Assumptions. The waste seam will be established by reviewing the estimated pit/trench boundaries (see Figure 2) and nature and extent of contamination characterization data. The boundaries of the waste seam will be agreed to by all stakeholders. The waste seam is defined as the actual waste and some margin of the surrounding soils, which ensures that essentially all of the contaminants of concern are included in the waste seam boundaries.

The confinement will provide an enclosure for those remedial activities that may result in contaminant release. Activities that could encounter waste include barrier wall excavation and well installation, if necessary.

3.1.4.2 Input. The input will be estimated boundaries of TRU-contaminated waste from the pits and trenches waste seams.

3.1.4.3 Requirements. The abovegrade confinement structure(s) shall be designed and constructed to meet the following applicable INEL building standards: "General Design Criteria" (DOE 6430.1A), ${ }^{8}$ Design and Evaluation Guidelines for Department of Energy Facilities Subjected to Natural Phenomenon Hazards, ${ }^{9}$ DOE-ID Architectural Engineering Standards, ${ }^{10}$ Operational Safety Design Criteria Manual, ${ }^{11}$ and the Industry Standard Uniform Building Code (UBC).

3.1.4.4 Output. The output will be a completed and operational abovegrade primary and secondary confinement structure over the excavation activity.

\subsubsection{Functional Subelement 4A.0 Confinement Ventilation System}

3.1.5.1 Background Technical Information and Assumptions. It is assumed that hazardous organic components in the ventilation system will not require treatment to meet Destruction Removal Efficiency (DRE) such as with incineration of organic gases. Any gases in the stream are assumed to be adequately removed by such equipment as charcoal filters.

3.1.5.2 Input. The input will be make-up air that is drawn into the outer confinement zone, and from the outer zone, the air cascades to the primary zone. The pressure in the primary zone will be less than the outer zone.

3.1.5.3 Requirements. Ventilation confinement schemes for the confinement (temporary) structure shall meet the requirements of DOE Order 6430.1A, section 1324 .

3.1.5.4 Output. The output will be filtered ventilation airflow that meets emission criteria in accordance with the permits and residual solid waste requirements. 


\subsubsection{Functional Subelement 4B.0 Confinement Ventilation Residuals/Solids Disposal}

3.1.6.1 Background Technical Information and Assumptions. Solid wastes are assumed to be classified into clean landfill, radioactive (LLW, TRU, and alpha-contaminated LLW), hazardous, and mixed radioactive hazardous wastes.

3.1.6.2 Input. The input will be operation wastes from the ventilation system.

3.1.6.3 Requirements. Packaging and/or overpacking will meet the acceptance requirements of a treatment or disposal facility.

3.1.6.4 Output. The output will be containers of solid wastes meeting the acceptance criteria for a treatment facility or disposal facility.

\subsubsection{Functional Subelement 5.0 Interim Vertical Barriers}

3.1.7.1 Background Technical Information and Assumptions. Partial construction of interim vertical barriers (in sections as opposed to the entire SDA all at once) is assumed to be adequate for stabilization on a value added risk reduction basis.

Existing data are assumed to be insufficient to administratively locate placement of vertical barriers. The adequacy of wall locations shall be verified for unknown waste locations before construction.

It is assumed that there are no potential criticalities in the unprocessed buried waste site. It is also assumed that a criticality will not occur in the confinement scheme.

3.1.7.2 Input. The input will be a volume of the disposal area with initial waste and soil characterization data and defined waste seam boundaries.

3.1.7.3 Requirements. The containment technology must reduce or prevent any lateral migration of contaminants away from the site. The containment technology must be able to contain, over a defined length of time, all potential waste materials in the buried waste site. This includes metals, wood, paper, asbestos, concrete, glass, plastics, organic wastes, inorganic wastes, oils and greases, rags, sludges, biological wastes, and flammable materials. ${ }^{2,5, c}$

The integrity of existing wells and boreholes (see Figure 3) within the boundaries of the remediation area must be maintained during and after containment construction.

The containment shall reduce the risk level in areas outside the containment to less than $10^{-6}$ for a defined length of time identified in the risk assessment. Construction methods shall enable a high confidence level of maintaining this reduction of risk for the defined length of time (10 to 50 years).

The containment technology must be capable of tying into the basalt layer below the waste pits and trenches. 
(0)

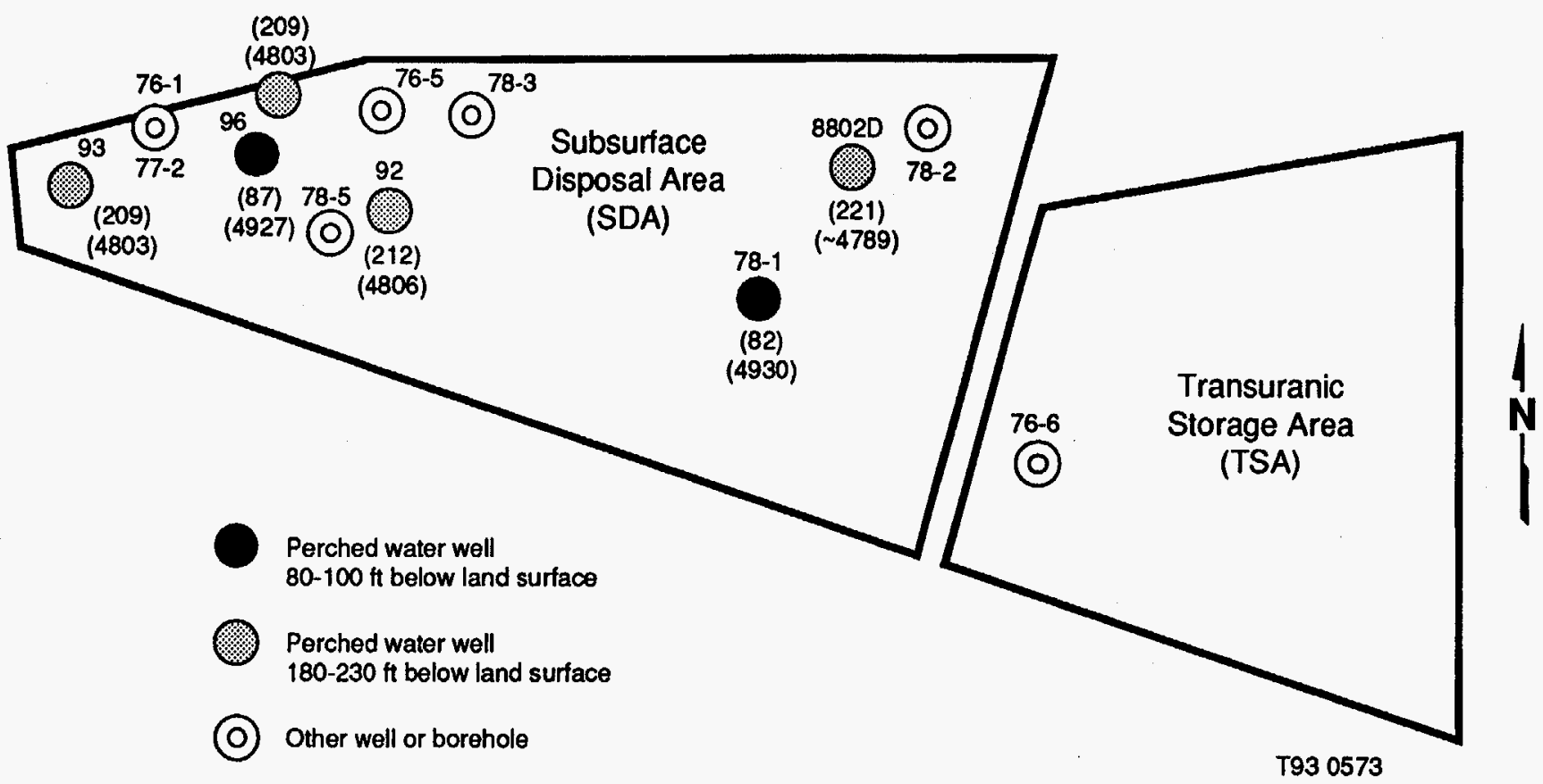

Figure 3. Existing wells and boreholes at the RWMC. 
3.1.7.4 Output. The output will be a horizontally isolated volume that confines the volatile organic compounds (VOCs), radionuclides, heavy metals, and inorganics to the volume inside of the barriers and reduces transport rates of these contaminants to a rate coinciding with a risk level of less than $10^{-6}$ for the defined length of time (10 to 50 years).

\subsubsection{Functional Subelement 6.0 Permanent Vertical Barriers}

3.1.8.1 Background Technical Information and Assumptions. The exterior containment walls, bottom barrier, and top cap shall extend to boundaries administratively determined and locally verified to include all previously buried solid waste. The assumptions for this subelement are

- Remediation of plumes that extend beyond these boundaries are assumed to be accomplished using vacuum vapor extraction or an other means and is not a part of this configuration option.

- Containment will be a permanent disposal site with a minimum lifetime for integrity of 1000 years.

- Existing data are insufficient to administratively locate the placement of interior or exterior walls. The adequacy of wall locations shall be verified for unknown waste locations before construction.

- There are no potential criticalities in the unprocessed buried waste site. It is also assumed that a criticality will not occur in the containment scheme.

3.1.8.2 Input. The input will be a volume of the disposal area with initial waste and soil characterization data and preinstalled interim vertical isolation barriers or defined waste seam boundaries.

3.1.8.3 Requirements. The containment technology must reduce or prevent any lateral migration of contaminants away from the site. The containment technology must be able to contain, over a defined length of time, all potential waste materials in the designated buried waste site. This includes metals, wood, paper, asbestos, concrete, glass, plastics, organic wastes, inorganic wastes, oils and greases, rags, sludges, biological wastes, and flammable materials., ${ }^{2,5, c}$

The integrity of existing wells and boreholes (see Figure 3) within the boundaries of the remediation area must be maintained during and after containment construction.

The containment shall reduce the risk level in areas outside the containment to less than $10^{-6}$ for a defined length of time identified in the risk assessment. Construction methods shall enable a high confidence level of maintaining this reduction of risk for the defined length of time (1000 years).

3.1.8.4 Output. The output will be a horizontally isolated volume that confines the VOCs, radionuclides, heavy metals, and inorganics to the volume inside of the barriers and reduces transport rates of these contaminants to a rate coinciding with a risk level of less than $10^{-6}$ for the defined length of time (1000 years). 


\subsubsection{Functional Subelement 7.0 Temporary Cap}

3.1.9.1 Background Technical Information and Assumptions. Partial interim capping (in sections as opposed to the entire SDA all at once) is assumed to be adequate for stabilization on a value added risk reduction basis.

The overburden is assumed to be left in place, and the cap is assumed to be placed over the overburden.

It is assumed that there are no potential criticalities in the unprocessed buried waste site. It is also assumed that a criticality will not occur in the containment scheme.

3.1.9.2 Input. The input will be a surface prepared and graded volume with or without interim or permanent vertical barriers. Also, initial soil and waste characterization data are known.

3.1.9.3 Requirements. The cap containment technology must reduce or eliminate migration of contaminants away from the site through the cap. The cap containment technology must be able to contain, over a defined length of time, all potential waste materials in the designated buried waste site. This includes metals, wood, paper, asbestos, concrete, glass, plastics, organic wastes, inorganic wastes, oils and greases, rags, sludges, biological wastes, and flammable materials. ${ }^{2,5, c}$

The integrity of existing wells and boreholes (see Figure 3) within the boundaries of the remediation area must be maintained during and after cap containment construction.

The containment reduces the risk level to less than $10^{-6}$ for a defined length of time identified in the risk assessment. Construction methods shall enable a high confidence level of maintaining this reduction of risk for the defined length of time (interim equates to 10 to 50 years and permanent equates to $>1000$ years).

3.1.9.4 Output. The output will be a vertically isolated (upward) volume that confines the VOCs, radionuclides, heavy metals, and inorganics to the volume inside of the barriers and reduces transport rates of these contaminants to a rate coinciding with a risk level of less than $10^{-6}$ for the defined length of time ( 10 to 50 years).

\subsubsection{Functional Subelement 8.0 Permanent Bottom Barrier}

3.1.10.1 Background Technical Information and Assumptions. The containment is assumed to be a permanent storage site with a minimum lifetime for integrity of 1000 years.

A horizontal barrier(s) shall be emplaced to facilitate containment of organics, volatile organics, radionuclides, and heavy metals from transport vertically downward.

It is assumed that there are no potential criticalities in the unprocessed buried waste site. It is also assumed that a criticality will not occur in the containment scheme. 
3.1.10.2 Input. The input will be a volume of the disposal area with initial waste and soil characterization data, preinstalled interim vertical isolation barriers, and defined waste seam boundaries.

3.1.10.3 Requirements. The containment technology must prevent excess migration of contaminants vertically downward over the bottom surface of the contained volume. The containment technology must be able to contain, over a defined length of time, all potential waste materials in the buried waste site. This includes voids, metals, wood, paper, asbestos, concrete, glass, plastics, organic wastes, inorganic wastes, oils and greases, rags, sludges, biological wastes, and flammable materials. ${ }^{2,5, c}$

The containment shall reduce the risk level to areas outside the containment to less than $10^{6}$ for the defined length of time identified in the risk assessment. Construction methods shall enable a high confidence level of maintaining this reduction of risk for the defined length of time (1000 years). The containment technology must not disturb the existing waste or protective barriers already in place.

The integrity of existing wells and boreholes (see Figure 3) within the boundaries of the remediation area must be maintained during and after containment construction.

3.1.10.4 Output. The output will be a vertically isolated (downward) volume that confines the VOCs, radionuclides, heavy metals, and inorganics to the volume inside of the barriers and reduces transport rates of these contaminants to a rate coinciding with a risk level of less than $10^{-6}$ for the defined length of time (1000 years).

\subsubsection{Functional Subelement 9.0 Monitor and Interim Assessment}

3.1.11.1 Background Technical Information and Assumptions. During and following emplacement of the cap, vertical barriers, drainage sump, and boreholes, a monitoring system is required to verify cap performance. Monitoring includes sampling and analysis of air, water, and soil. The monitoring method is constructed to provide quality, verifiable data quantifying that isolation is effective and parameters of interest to risk assessment are being measured.

The interim isolation reduces the risk level to less than $10^{6}$ for a defined length of time identified in the risk assessment.

Construction methods enable a high confidence level of maintaining this reduction of risk for the defined length of time (interim equates to 10 to 50 years and permanent equates to $>1000$ years).

3.1.11.2 Input. The input will be a contained volume of wastes contaminated with VOCs, radionuclides, heavy metals, and inorganics isolated by barriers with reduced transport of the contaminants outside (downward, upward, and sideways) of the barriers.

3.1.11.3 Requirements. The monitoring activities shall provide data as necessary to enable an interim risk assessment based on reduction of risk from organics, heavy metals, radionuclides, and inorganic contaminants, and the following: 
- The system shall monitor for leakage of the above contaminants from the contained volume through air and water pathways and verify general performance on nonhazardous substances such as total suspended particulates or dissolved solids in water.

- The system shall provide the type, quantity, and quality of data necessary to maintain daily operations and validate performance assessment requirements during the storage period.

- The data from the system shall verify the efficacy of the containment structure by providing information required to meet 30-year CERCLA closure and other long-term assessment requirements.

3.1.11.4 Output. The output will be

- Data from monitoring systems and samples for laboratory analysis

- Plan of recommended action with supporting bases (background and verification data) for input into the comprehensive ROD for final action

- Recommendation (if required) for mitigation of contaminant migration from confinement.

\subsubsection{Functional Subelement 10.0 Vapor Extraction}

3.1.12.1 Background Technical Information and Assumptions. It is assumed that remaining hazardous volatile organics will be extracted based on overall environmental risk reduction requirements.

3.1.12.2 Input. The input will be a contained and/or bounded volume for the removal of volatile organic compounds.

3.1.12.3 Requirements. The vapor extraction subsystem shall be a passive or active system that collects VOCs from the contained volume for subsequent treatment. The need for the subsystem shall be based on a risk assessment.

3.1.12.4 Output. The output will be VOCs potentially contaminated with radioactive particulate matter.

\subsubsection{Functional Subelement 10A.0 Offgas Treatment System}

3.1.13.1 Background Technical Information and Assumptions. It is assumed that the offgas treatment system will not need to be designed as critically safe based on the results of safety and risk analyses.

3.1.13.2 Input. The input will be vapors and offgas from the vapor extraction subsystem.

3.1.13.3 Requirements. The vapors and offgas delivered from the vapor extraction system shall be treated. DRE of $99.9999 \%$ shall be performed for EPA Resource Conservation and 
Recovery Act hazardous compounds. The entire offgas stream shall be HEPA filtered for radioactive particulates.

No liquid wastes shall be allowed as an output waste form. The solid waste shall be packaged to meet the acceptance criteria of an existing treatment facility or disposal site.

3.1.13.4 Output. The output will be a packaged residual solid waste in various forms and classified as clean landfill, or radioactive ( $L L W$, alpha-contaminated LLW, and TRU) wastes. These wastes shall meet the acceptance criteria for an existing treatment facility or a disposal site.

Offgas emissions will be within the limitations of applicable permits and licenses.

\subsubsection{Functional Subelement 10B.0 Offgas Treatment Residual Solid Disposal}

3.1.14.1 Background Technical Information and Assumptions. Permanent disposal of offgas residual solid waste is assumed to exist.

The solid wastes from this activity are assumed to be transferred to an offsite disposal facility.

3.1.14.2 Input. The input will be packaged solid waste.

3.1.14.3 Requirements. The solid waste shall meet the acceptance criteria of a disposal site for the particular waste classification.

\subsubsection{Output. None.}

\subsubsection{Functional Subelement 11.0 Final Action}

3.1.15.1 Background Technical Information and Assumptions. This functional subelement assumes that additional remedial action (following containment and stabilization) is necessary to meet final site closure requirements. Determination of the action will depend on assessment of monitoring data, risk analysis, technology availability and effectiveness, and regulatory requirements. No action could be a possible final action.

3.1.15.2 Input. The input will be contained and stabilized volume of wastes and soil classified as interim isolation.

3.1.15.3 Requirements. The final action for the isolated and stabilized volume shall be based on the comprehensive ROD and a final risk assessment. No attempt will be made at this point to identify further requirements for any final action. A permanent (1000 year) cap may be one alternative pending future decisions.

3.1.15.4 Output. There will be no further action. 


\section{REFERENCES}

1. J. G. Richardson, M. J. Rudin, M. C. O'Brien, J. L. Morrison, and B. Raivo, INEL Operable Unit 7-13 Retrieval/Ex Situ Thermal Treatment Configuration Operations, EGG-WTD-10204, July 1992.

2. M. C. O'Brien, Performance-Based Technology Selection Description Report, EGG-WTD-9989, May 1992.

3. Idaho National Engineering Laboratory, Federal Facility Agreement and Consent Order, ADN: 1088-06-29-120, May 1991.

4. K. M. Kostelnik, Buried Waste Integrated Demonstration Strategy Plan, EGG-WTD-10610, December 1992.

5. D. A. Arrenholz and J. L. Knight, $A$ Brief Analysis and Description of Transuranic Wastes in the Subsurface Disposal Area of the Radioactive Waste Management Complex at INEL, EGG-WTD9438, Rev. 1, August 1991.

6. U. S. Department of Energy Idaho Operations Office, INEL Low-Level Radioactive Waste Acceptance Criteria, DOE/ID-10112, Rev. 4, October 1991.

7. U. S. Department of Energy Idaho Operations Office, INEL Transuranic Waste Acceptance Criteria, DOE/ID-10074, Rev. 5, (Draft), October 1992.

8. U. S. Department of Energy, "General Design Criteria," DOE Order 6430.1A, April 1989.

9. University of California Research Laboratory, Design and Evaluation Guidelines for Department of Energy Facilities Subjected to Natural Phenomenon Hazard, UCRL-15910, October 1989.

10. U. S. Department of Energy Idaho Operations Office, DOE-ID Architectural Engineering Standards, September 1991.

11. U. S. Department of Energy Idaho Operations Office, Operational Safety Design Criteria Manual, DOE/ID-12044, April 1985. 


\section{Appendix A}

\section{INEL OU 7-13 Waste Pit and Trench Characteristics Tables ${ }^{\mathrm{a}}$}

a. D. A. Arrenholz and J. L. Knight, A Brief Analysis and Description of Transuranic Wastes in the Subsurface Disposal Area of the Radioactive Waste Management Complex at the INEL, EGG-WTD9438, Rev. 1, August 1991. 
A-2 
Table A-1. Summary of volumes of pits, trenches, wastes, and associated soils in selected pits and trenches at the SDA.

\begin{tabular}{|c|c|c|c|c|c|c|c|}
\hline & Location & $\begin{array}{l}\text { Excavated } \\
\text { volume } \\
\mathrm{ft}^{3}\end{array}$ & $\begin{array}{l}\text { Waste } \\
\text { container } \\
\text { volume } \\
\mathrm{ft}^{3}\end{array}$ & $\begin{array}{c}\text { Soil } \\
\text { volume } \\
\mathrm{ft}^{3}\end{array}$ & $\begin{array}{c}\text { Overburden } \\
\text { volume } \\
\mathrm{ft}^{3}\end{array}$ & $\begin{array}{c}\text { Subsidence } \\
\text { volume } \\
\mathrm{ft}^{3}\end{array}$ & $\begin{array}{l}\text { Underburden } \\
\text { volume } \\
\mathrm{ft}^{3}\end{array}$ \\
\hline & T 1 & 81,243 & 16,897 & 64,346 & 30,563 & 0 & NA \\
\hline & T 2 & 86,932 & 6801 & 80,131 & 26,544 & 0 & NA \\
\hline & T 3 & 90,658 & 12,375 & 78,284 & 26,664 & 689 & NA \\
\hline & T 4 & 93,828 & 17,788 & 76,040 & 26,808 & 750 & NA \\
\hline & T 5 & 112,362 & 17,905 & 94,457 & 29,245 & 0 & NA \\
\hline & T 6 & 91,982 & 15,475 & 76,507 & 26,856 & 1800 & NA \\
\hline & T 7 & 87,278 & 10,729 & 76,549 & 29,093 & 0 & NA \\
\hline & T 8 & 97,752 & 14,143 & 83,610 & 26,880 & 156 & NA \\
\hline & Т 9 & 83,633 & 13,237 & 70,396 & 28,891 & 0 & NA \\
\hline & Т 10 & 91,474 & 9107 & 82,368 & 26,904 & 923 & NA \\
\hline & P 1 & 379,135 & 81,819 & 297,316 & 107,884 & 0 & 169,532 \\
\hline & P 2 & $1,020,359$ & 418,357 & 602,002 & 425,975 & 455 & 544,852 \\
\hline & P 3 & 368,394 & 102,059 & 266,335 & 236,150 & 0 & 70,845 \\
\hline & P 4 & 955,309 & 388,494 & 566,815 & 787,343 & $\mathbf{0}$ & 367,427 \\
\hline & P 5 & 796,729 & 286,612 & 510,117 & 368,236 & 18 & 100,428 \\
\hline & P 6 & 447,515 & 223,898 & 223,617 & 409,313 & 0 & 191,013 \\
\hline & P 9 & 342,416 & 150,690 & 191,726 & 256,812 & 353 & 149,807 \\
\hline & P 10 & $1,052,941$ & 538,865 & 514,076 & 784,084 & $\mathbf{0}$ & 526,471 \\
\hline & Total & $6,279,940$ & $2,325,251$ & $3,954,692$ & $3,654,245$ & 5144 & $2,120,375$ \\
\hline a. & \multicolumn{2}{|c|}{$\begin{array}{l}\text { Total volume of pits and trenches }= \\
\text { Total volume of waste containers }= \\
\text { Total volume of contaminated soil }= \\
\text { Total volume of contaminated } \\
\text { wastes and soils }\end{array}$} & $\begin{array}{l}0 \mathrm{ft}^{3} \\
1 \mathrm{ft}^{3} \\
6 \mathrm{ft}^{3} \\
7, \mathrm{ft}^{3}\end{array}$ & & & & \\
\hline
\end{tabular}


Table A-2. Excavation details for selected pits at the SDA.

\begin{tabular}{|c|c|c|c|c|c|c|c|c|}
\hline Pit no. & $\begin{array}{c}\text { Mean } \\
\text { surface } \\
\text { elevation } \\
\text { (ft) }\end{array}$ & $\begin{array}{l}\text { Mean basal } \\
\text { surface } \\
\text { elevation } \\
\text { (ft) }\end{array}$ & $\begin{array}{c}\text { Average } \\
\text { estimated } \\
\text { overburden } \\
\text { (ft) }\end{array}$ & $\begin{array}{c}\text { Estimated } \\
\text { excavated } \\
\text { depth } \\
\text { (ft) }\end{array}$ & $\begin{array}{c}\text { Estimated } \\
\text { width } \\
(\mathrm{ft})\end{array}$ & $\begin{array}{l}\text { Estimated } \\
\text { length } \\
\text { (ft) }\end{array}$ & $\begin{array}{c}\text { Surface } \\
\text { area } \\
\left(\mathrm{ft}^{2}\right)\end{array}$ & $\begin{array}{l}\text { Excavated } \\
\text { volume } \\
\left(\mathrm{ft}^{3}\right)\end{array}$ \\
\hline 1 & 5016.3 & 4995 & $3.5(5.5)^{\mathrm{a}}$ & 12.0 & 68 & 455 & 30,824 & 379,135 \\
\hline 2 & 5014.1 & 4994 & $4.3(5.5)^{\mathrm{a}}$ & 10.3 & 87 & 1150 & 99,064 & $1,020,359$ \\
\hline 3 & 5014.3 & 5000 & $5.0(1.5)^{\mathrm{a}}$ & 7.8 & 100 & 472 & 47,230 & 368,394 \\
\hline 4 & 5013.1 & 4993 & $7.5(3.5)^{\mathrm{a}}$ & 9.1 & 104 & 1000 & 104,979 & 955,309 \\
\hline 5 & 5011.9 & 4993 & $5.5(1.5)^{\mathrm{a}}$ & 11.9 & 150 & 450 & 66,952 & 796,729 \\
\hline 6 & 5012.2 & 4993 & $7.5(3.5)^{\mathrm{a}}$ & 8.2 & 120 & 455 & 54,575 & 447,515 \\
\hline 9 & 5010.5 & 4993 & $6.0(3.5)^{\mathrm{a}}$ & 8.0 & 130 & 330 & 43,802 & 342,416 \\
\hline 10 & 5104.1 & 4993 & $7.0(4.7)^{\mathrm{a}}$ & 9.4 & 120 & 940 & 112,015 & $1,052,941$ \\
\hline
\end{tabular}

a. The value in brackets is the depth of the soil left in place over the basalt when the pits were excavated. 
Table A-3. Excavation details for selected trenches at the SDA.

\begin{tabular}{|c|c|c|c|c|c|c|c|c|}
\hline $\begin{array}{c}\text { Trench } \\
\text { no. }\end{array}$ & $\begin{array}{c}\text { Mean } \\
\text { surface } \\
\text { elevation } \\
\text { (ft) }\end{array}$ & $\begin{array}{c}\text { Mean } \\
\text { basalt } \\
\text { surface } \\
\text { elevation } \\
\text { (ft) }\end{array}$ & $\begin{array}{c}\text { Average } \\
\text { estimated } \\
\text { overburden } \\
\text { (ft) }\end{array}$ & $\begin{array}{c}\text { Estimated } \\
\text { excavated } \\
\text { depth }^{\mathrm{a}} \\
(\mathrm{ft})\end{array}$ & $\begin{array}{c}\text { Estimated } \\
\text { width } \\
\text { (ft) }\end{array}$ & $\begin{array}{l}\text { Estimated } \\
\text { length } \\
(\mathrm{ft})\end{array}$ & $\begin{array}{c}\text { Surface } \\
\text { area } \\
\left(\mathrm{ft}^{2}\right)\end{array}$ & $\begin{array}{c}\text { Excavated } \\
\text { volume } \\
\left(\mathrm{ft}^{3}\right)\end{array}$ \\
\hline 1 & $5,012.9$ & 4997 & 3.8 & 10.1 & 7 & 1149 & 8043 & 81,243 \\
\hline 2 & $5,012.1$ & 4993 & 4.0 & 13.1 & 6 & 1106 & 6636 & 86,932 \\
\hline 3 & $5,012.6$ & 4993 & 4.0 & 13.6 & 6 & 1111 & 6666 & 90,658 \\
\hline 4 & $5,013.0$ & 4993 & 4.0 & 14.0 & 6 & 1117 & 6702 & 93,828 \\
\hline 5 & $5,013.6$ & 4997 & 3.8 & 14.6 & 6.6 & 1166 & 7696 & 112,362 \\
\hline 6 & $5,012.7$ & 4993 & 4.0 & 13.7 & 6 & 1119 & 6714 & 91,982 \\
\hline 7 & $5,014.2$ & 4997 & 3.8 & 11.4 & 6.6 & 1161 & 7656 & 87,278 \\
\hline 8 & $5,013.1$ & 4993 & 4.0 & 14.1 & 6 & 1120 & 6720 & 97,752 \\
\hline 9 & $5,013.8$ & 4997 & 3.8 & 11.0 & 6.6 & 1152 & 7603 & 83,633 \\
\hline 10 & $5,012.6$ & 4993 & 4.0 & 13.6 & 6 & 1121 & 6726 & 91,474 \\
\hline
\end{tabular}

a. The excavated depth was calculated by taking the difference between the surface and basalt elevations. From this value, the estimated overburden was subtracted out. Finally, an additional $2 \mathrm{ft}(1 \mathrm{ft}$ for basalt overburden and $1 \mathrm{ft}$ for depth of buried waste from original surface elevation) were subtracted out. 
Table A-4. Various physical characteristics of soil and sediment samples from the RWMC wells.

\section{Depth interval}

\begin{tabular}{|c|c|c|c|c|c|c|c|}
\hline $\begin{array}{l}\text { Well } \\
\text { no. }\end{array}$ & $\begin{array}{c}\text { Top } \\
\text { (ft in.) }\end{array}$ & $\begin{array}{l}\text { Bottom } \\
\text { (ft in.) }\end{array}$ & $\begin{array}{c}\text { Specific } \\
\text { gravity }\end{array}$ & $\begin{array}{c}\text { Bulk } \\
\text { density } \\
\left(\mathrm{g} / \mathrm{cm}^{3}\right)\end{array}$ & $\begin{array}{l}\text { Porosity } \\
\text { (percent) }\end{array}$ & $\begin{array}{l}\text { Moisture } \\
\text { content } \\
\text { (percent) }\end{array}$ & $\begin{array}{c}\text { Vertical } \\
\text { hydraulic } \\
\text { conduct } \\
\text { (m/day) }\end{array}$ \\
\hline 92 & 6 & 5 & 2.65 & 1.87 & 34.3 & 12.9 & $5.5 \times 10^{-4}$ \\
\hline 94 & 6 & 83 & 2.67 & 2.02 & 30.5 & 16.4 & $2.7 \times 10^{-4}$ \\
\hline 95 & 10 & 126 & 2.66 & 1.70 & 41.0 & 13.2 & $7.9 \times 10^{-3}$ \\
\hline
\end{tabular}

Table A-5. Properties of soil and sediment samples from the RWMC wells.

\begin{tabular}{|c|c|c|c|c|c|c|c|c|c|}
\hline \multirow[b]{2}{*}{ Well no. } & \multicolumn{2}{|c|}{ Depth Interval } & \multicolumn{3}{|c|}{$\begin{array}{l}\text { Particle size } \\
\text { distribution } \\
(\%)^{\mathrm{a}}\end{array}$} & \multicolumn{3}{|c|}{$\begin{array}{l}\text { Clay minerals } \\
\text { (\%) moisture }\end{array}$} & \multirow{2}{*}{$\begin{array}{c}\text { Cation } \\
\text { exchange } \\
\text { capacity } \\
(\mathrm{meg} / 100 \mathrm{~g})\end{array}$} \\
\hline & $\begin{array}{l}\text { Top } \\
\text { (ft in.) }\end{array}$ & $\begin{array}{l}\text { Bottom } \\
\text { (ft in.) }\end{array}$ & Clay & Silt & Sand & Kaolinite & Illite & Montmorillonite & \\
\hline 92 & 26 & 5 & 21.2 & 48.8 & 30.1 & 2 & 5 & 5 & 14 \\
\hline 94 & 66 & 83 & 38.7 & 56.5 & 4.8 & 3 & 9 & 4 & 23 \\
\hline 95 & 10 & 126 & 38.5 & 55.6 & 5.9 & 1 & 4 & 3 & 17 \\
\hline \multicolumn{3}{|l|}{ Median $^{\mathrm{b}}$} & 35.3 & 56.0 & 7.3 & 2 & 7 & 6 & 21 \\
\hline \multicolumn{10}{|c|}{$\begin{array}{l}\text { a. Clay }<0.004 \mathrm{~mm} \\
\text { Silt } 0.004-0.062 \mathrm{~mm} \\
\text { Sand } 0.062-<2.00 \mathrm{~mm} \text {. }\end{array}$} \\
\hline Media & of eight sa & aples. & & & & & & & \\
\hline
\end{tabular}


Table A-6. Particle size distribution for subpit samples (in percent of analyzed sample). ${ }^{a}$

\begin{tabular}{|c|c|c|c|c|c|c|c|}
\hline $\begin{array}{l}\text { Sampleb } \\
\text { no. }\end{array}$ & $\begin{array}{l}\text { Depth } \\
\text { (m) }\end{array}$ & $\begin{array}{c}\text { Clay } \\
<0.004 \\
\mathrm{~mm}\end{array}$ & $\begin{array}{c}\text { Silt } \\
0.004- \\
0.0625 \\
\mathrm{~mm}\end{array}$ & $\begin{array}{l}\text { Sand very } \\
\text { fine } \\
0.0625- \\
0.125 \mathrm{~mm}\end{array}$ & $\begin{array}{c}\text { Sand } \\
\text { fine } \\
0.125 \text { - } \\
0.25 \mathrm{~mm}\end{array}$ & $\begin{array}{c}\text { Sand } \\
\text { medium } \\
0.25-0.5 \mathrm{~mm}\end{array}$ & $\begin{array}{c}\text { Sand }^{c} \\
\text { coarse } \\
0.5-1 \mathrm{~mm}\end{array}$ \\
\hline EWR-1-4 & 0.91 & 53.3 & 38.5 & 4.8 & 2.3 & 0.9 & 0.1 \\
\hline EWR-1-3 & 1.22 & 41.0 & 30.1 & 11.0 & 17.7 & 0.2 & 0 \\
\hline EWR-1-2 & 1.52 & 54.7 & 40.1 & 4.1 & 0.7 & 0.2 & 0.1 \\
\hline EWR-1-1 & 1.83 & 23.5 & 69.8 & 6.0 & 0.6 & 0 & 0.1 \\
\hline \multicolumn{8}{|c|}{$\begin{array}{l}\text { a. Analyzed by the USGS Hydrologic Laboratory, Denver, Colorado. } \\
\text { b. All samples from surficial deposits. } \\
\text { c. No particles coarser than } 1 \mathrm{~mm} \text { observed. }\end{array}$} \\
\hline
\end{tabular}

Table A-7. Mineralogy for subpit samples (in percent of analyzed sample). ${ }^{\mathrm{a}}$

\begin{tabular}{|c|c|c|c|c|c|c|c|c|}
\hline $\begin{array}{l}\text { Sample } \\
\text { no. }\end{array}$ & $\begin{array}{l}\text { Depth } \\
\text { (m) }\end{array}$ & Quartz & $\begin{array}{l}\text { Potassium } \\
\text { feldspar }\end{array}$ & Plagioclase & Calcite & $\begin{array}{l}\text { Pryoxene } \\
\text { dioxide }\end{array}$ & $\begin{array}{c}\text { Clay } \\
\text { minerals }\end{array}$ & $\begin{array}{c}\text { Total } \\
\text { percent }\end{array}$ \\
\hline EWR-1-4 & 0.91 & 27 & $\leq 5$ & 11 & 1 & 4 & 70 & $113+^{c}$ \\
\hline EWR-1-3 & 1.22 & 29 & $\leq 6$ & 10 & 0 & 9 & 55 & $103+$ \\
\hline EWR-1-2 & 1.52 & 15 & $\leq 3$ & 6 & 41 & $\leq 9$ & 25 & $87+$ \\
\hline EWR-1-1 & 1.83 & 29 & 5 & 12 & 13 & $\leq 9$ & 40 & $99+$ \\
\hline \multicolumn{9}{|c|}{$\begin{array}{l}\text { a. Analyzed by the USGS Hydrologic Laboratory, Denver, Colorado. } \\
\text { b. All samples from surficial deposits. } \\
\text { c. Due to high percentage of clay minerals. }\end{array}$} \\
\hline
\end{tabular}


Table A-8. Clay mineralogy of selected surficial sediment samples (in percent of total clay minerals/percent of original bulk samples). ${ }^{\text {a }}$

\begin{tabular}{|c|c|c|c|c|c|c|c|c|}
\hline Sample & $\begin{array}{l}\text { Depth } \\
\text { (m) }\end{array}$ & Chlorite & Illite & $\begin{array}{c}\text { Mixed layer } \\
\text { clays } \\
\text { (illite/smectite) }\end{array}$ & Smectite & Kaolinite & $\begin{array}{l}\text { Cation } \\
\text { exchange } \\
\text { capacity }\end{array}$ & $\begin{array}{c}\text { Carbonate content } \\
\left(\mathrm{CaCO}_{3}\right) \\
\text { percent }\end{array}$ \\
\hline EWR-1-4 & 0.91 & $0 / 03$ & $6 / 25$ & $45 / 32$ & $13 / 9$ & $6 / 4$ & 27 & 0 \\
\hline EWR-1-3 & 1.22 & $0 / 03$ & $0 / 16$ & $48 / 26$ & $15 / 9$ & $6 / 3$ & 27 & 2.3 \\
\hline EWR-1-2 & 1.52 & $0 / 03$ & $6 / 9$ & $31 / 8$ & $24 / 6$ & $9 / 2$ & 11 & 36.1 \\
\hline EWR-1-1 & 1.83 & $0 / 03$ & $2 / 12$ & $30 / 12$ & $26 / 10$ & $12 / 5$ & 11 & 10.8 \\
\hline
\end{tabular}

